\title{
Effect of feeding cottonseed cake on male fertility in rabbit
}

\section{A Kenfack ${ }^{1 *}$, JK Chombong ${ }^{1}$, F Ngoula ${ }^{1}$, NB Vemo $^{1}$, AMM Tsambou $^{1}$, GMZ Zeukeng ${ }^{3}$, B Mama $^{2}$, J Tchoumboué ${ }^{1}$}

\begin{abstract}
${ }^{1}$ Department of Animal Science, Faculty of Agronomy and Agricultural Science, University of Dschang, Dschang-Cameroon; 'Food control Centre, N'Djamena-Tchad republic; ${ }^{3}$ Menoua Delegation of Agriculture,
\end{abstract} Dschang-Cameroon

\begin{abstract}
In order to study the effects of cottonseed cake on the fertility of the male rabbit, 60 animals (40 bucks and 20 does) were used. Males were 3 months old at the beginning of the essay, and the females were multiparous. Males were divided into 4 identical groups. Four diets containing 0, 6, 12 and $18 \%$ of cottonseed cake were formulated and randomly allotted to different groups of males. All the females received the same diet (6\%). The treatment lasted for 90 days. At the end of that period, 5 males were sacrificed per lot and the rest were allowed to mate each with an untreated female before being sacrificed in turn. No significant difference $(p>0.05)$ was observed among rations for the volume of testis and weight of reproductive organs. Histological study of the testes revealed no abnormality. In the presence of an untreated female, hundred percent of rabbits realized mounting and ejaculated whichever the cottonseed cake level. Nevertheless, the volume of the ejaculate was significantly $(p>0.05)$ low in rabbit fed $6 \%$ cottonseed cake $(0.86$ vs $1.66,12 \%)$. The spermatozoa concentration in the cauda epididymis was higher in rabbit given cottonseed cake than in control, although not significantly $(p>0.05)$. The adverse effects of the toxicant contained in cottonseed cake occurred at $18 \%$ inclusion. The result showed that it is not possible to generalize the upper limit of inclusion of cottonseed cake in the ration formulation
\end{abstract}

Key words: Cottonseed, dietary gossypol, intoxication, nutritive components, spermatogenesis, sperm quality

Bangladesh Animal Husbandry Association. All rights reserved.

Bang. J. Anim. Sci. 2015. 44 (1): 16-20

\section{Introduction}

Cottonseed cake is a by-product obtained by extracting oil from the cottonseed. It is a good source of protein and energy and is abundant in central African countries. For those reasons, it is generally used in the ration of domestic animals. Cotton and cotton products contain gossypol, a substance reported to be toxic (Mena et al. 2004; Jalees et al. 2011) to animals, mainly monogastric because polygastrics are able to detoxify free gossypol by converting it into bound gossypol in the rumen, thereby impeding its absorption into the blood (Mena et al. 2004). The exposition of monogastric to gossypol would affect negatively certain of their functions. Thus gossypol has long been used as a contraceptive agent (Waites et al. 1998; Romualdo et al. 2013).

Cottonseed cake is highly concentrated in proteins (40-46\%) and fibers (Dabrowski et al. 2000; Amoa et al. 2012). It is cheaper compared to most of the proteins sources used in Cameroon such as soya bean meal and groundnut cake. It is used in high concentration in chicken, guinea-pig and rabbit. In certain circumstances, due to the rarity associated with high cost of other protein sources, cottonseed cake is mixed alone to energy sources in the preparation of animal feed. Thus, to reach an adequate protein rate in the ration, a great concentration of cottonseed cake, probably of gossypol would be fed to animals. The objective of this study is to contribute to a best understanding of the toxic effects of cottonseed cake on rabbit buck reproductive system.

\section{Material and methods}

Sixty crossbreed medium sized rabbits, whose 40 bucks and 20 does, were used in this study. They were born in the teaching and experimental farm of Dschang University. Males were 3 to 4 months old at the starting of the trial. Females were multiparous and used to test the male fertility at the end of feeding treatment. Animals were housed in wire cages of identical dimensions 
$(98 \mathrm{~cm} \times 48 \mathrm{~cm} \times 27 \mathrm{~cm})$, in a building made up of a wire-netting at its upper third. Each cage was equipped with a feeder and a water trough.

The animals were subjected to four experimental rations R1, R2, R3 and R4 containing 0, 6, 12.15 and $17.54 \%$ cottonseed cake respectively. The chemical characteristics of the experimental diets are shown in Table 1.

Table 1. Chemical characteristics of rations

\begin{tabular}{lcccc}
\hline \multirow{2}{*}{ Ingredients } & \multicolumn{4}{c}{ Chemical characteristics } \\
\cline { 2 - 5 } & $\mathrm{R} 1$ & $\mathrm{R} 2$ & $\mathrm{R} 3$ & $\mathrm{R} 4$ \\
\hline${ }^{*}$ Gossypol (mg/100g diet) & 0.00 & 8.4 & 17.01 & 24.56 \\
Crude proteins (\%) & 15.21 & 16.85 & 18.49 & 20.10 \\
Crude fibres (\%) & 11.10 & 11.26 & 11.43 & 11.84 \\
Calcium (\%) & 0.66 & 0.66 & 0.67 & 0.67 \\
Phosphorous (\%) & 0.92 & 0.91 & 0.89 & 0.88 \\
ME (Kcal.kg-1DM) & 2003.20 & 2016.68 & 2043.99 & 2061.61 \\
\hline
\end{tabular}

*The percentage of gossypol measured in cottonseed cake was $1400 \mathrm{mg} / \mathrm{kg}$

Male rabbits were divided into 4 groups of 10 animals in each considering the similarity of body weight. They were allocated randomly to four experimental diets. After 4 months of trial, half of the bucks of each lot were sacrificed, reproductive organs were collected, epididymal sperm were analyzed and testes were processed for histology. The second half was kept alive for the collection and evaluation of semen. They were then allowed to mate each with an untreated multiparous female for the evaluation of the fertility. Only males were subjected to feeding treatment.

After opening the abdomen, testes and epididymis, vas deferens and accessory glands were removed, cleaned of fat and weighed. The volume of the testis was determined by immersing a testis in beaker containing water, and the variation of water volume in the beaker was considered the volume of the testis.

The cauda epididymis was removed, weighed and thereafter minced in $0.9 \% \mathrm{NaCl}$ solution at $37^{\circ} \mathrm{C}$. Regarding the ejaculates collection, it was done by the use of a rabbit artificial vagina; ejaculated semen was collected directly into a graduated tube. The epididymal spermatozoa and ejaculates characteristics were evaluated following the guidelines of WHO (2010). Following those guideline, the volume of the ejaculate was measured by reading directly from the graduated collection tube. The motility was evaluated by counting separately the motile and immotile sperms on slide. For the concentration, the diluted ejaculate or the solution prepared from the tail of epididymis was allowed to settle in Thomas haematocytometer chamber (the volume of the chamber is fixed), spermatozoa were counted and the concentration was calculated.

The testes were subjected to histological study. To do this, testes were immersed in Bouin's solution for fixation, dehydrated in graded ethanol series, cleared in xylen, hardened in paraffin and cut with a microtome. The pieces thus obtained were deparaffinized, stained with hematoxylin and eosin and observed under a light microscope at 400X. Data were expressed as mean \pm standard deviation and percentage. The analysis of variance with one factor was used to compare means; in case of any significant difference, the DMRT was used to separate means. The chi-square test was used for the comparison of percentages.

\section{Results}

The volume and weight of reproductive organs were comparable $(p>0.05)$ among rabbits receiving cottonseed cake and controls (Table 2 ).

Table 2. Effects of cottonseed cake on the volume and weight of internal genitalia in rabbit buck

\begin{tabular}{lcccc}
\hline $\begin{array}{l}\text { Volume and } \\
\text { weight of }\end{array}$ & \multicolumn{4}{c}{ Level of incorporation of cottonseed cake } \\
\cline { 2 - 5 } genitalia & $0(\mathrm{n}=5)$ & $6(\%)$ & $12.15(\%)$ & $17.54(\%)$ \\
$(\mathrm{n}=5)$ & $(\mathrm{n}=5)$ & $(\mathrm{n}=5)$ \\
\hline Testis $(\mathrm{ml})$ & $2.46 \pm 0.73$ & $2.74 \pm 0.57$ & $2.52 \pm 0.53$ & $2.66 \pm 0.52$ \\
Testis $(\mathrm{g})$ & $2.62 \pm 0.66$ & $2.79 \pm 0.48$ & $2.77 \pm 0.37$ & $2.71 \pm 0.45$ \\
CE (g) & $0.54 \pm 0.19$ & $0.64 \pm 0.22$ & $0.51 \pm 0.12$ & $0.58 \pm 0.19$ \\
VD (g) & $0.83 \pm 0.29$ & $1.03 \pm 0.31$ & $1.03 \pm 0.10$ & $0.76 \pm 0.07$ \\
AG (g) & $2.68 \pm 0.79$ & $3.22 \pm 0.76$ & $3.12 \pm 0.86$ & $3.02 \pm 1.09$ \\
\hline
\end{tabular}

$C E$, cauda epididymis; VD, vas deferent; $A G$, accessory glands; Means in the same row did not significantly differed $(p>0.05) ; n$, number of animals

Cottonseed cake did not affect the histological structure of testis in rabbits (Figure 1). Indeed, no alteration was noticed on the seminiferous epithelium, be it in control or in treated rabbit. 
Among all sections observed, no vacuole has
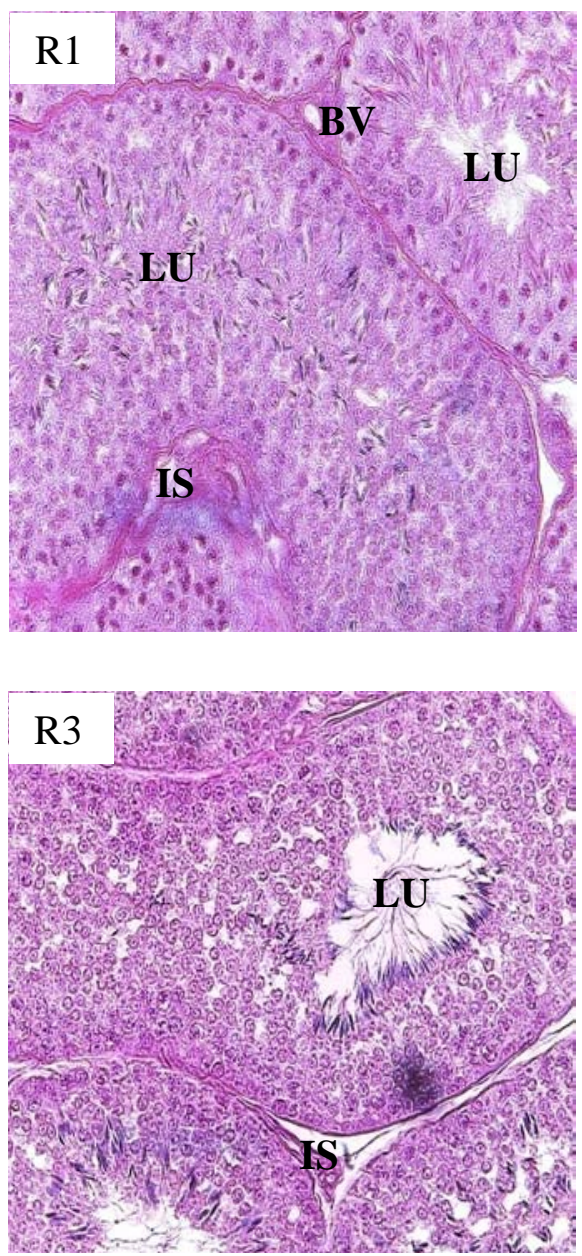

been shown whatever the treatment.
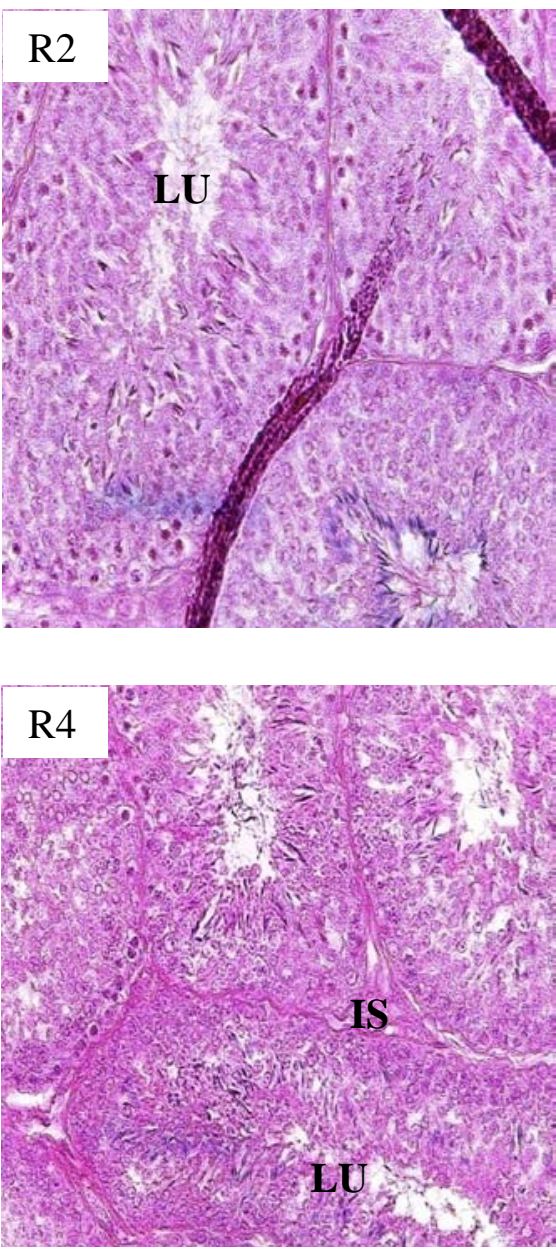

Figure 1. Histological structure of rabbit testis (R1: control; R2: ration with $6 \%$ cottonseed; R3: ration with $12.15 \%$ cottonseed; $R 4$ : ration with $17.54 \%$ cottonseed); Lu, lumen; BV, blood vessel; IS, interstitial space; Note: the absence of abnormalities whatever the treatment

The numbers of sperms per gram (g) of epididymis were significantly $(P<0.05)$ higher in rabbits whose diet contained the highest concentration of cottonseed cake (Table 3). The percentage of motile sperms in the cauda epididymis did not increase significantly ( $p>0.05)$ in animal fed cottonseed cake when compared to controls (Table 3 ).

All the rabbit buck in the presence of female emitted the semen (Table 4). However, the amount of semen ejaculated was significantly $(\mathrm{P}<0.05)$ higher in rabbits fed $12 \%$ cottonseed cake compared to those consuming $6 \%$.
Table 3. Effects of cottonseed cake on the number and motility of cauda epididymis sperm

\begin{tabular}{lcccc}
\hline Epididymis & \multicolumn{4}{c}{ Level of incorporation of cottonseed cake (\%) } \\
\cline { 2 - 5 } spermatozoa & $0(\mathrm{n}=5)$ & $6(\mathrm{n}=5)$ & $12.15(\mathrm{n}=5)$ & $17.54(\mathrm{n}=5)$ \\
\hline Number/cauda & $248.44^{\mathrm{a}}$ & $319.43^{\mathrm{a}}$ & $261.96^{\mathrm{a}}$ & $404.00^{\mathrm{a}}$ \\
$(\mathrm{x} \mathrm{106})$ & \pm 116.44 & \pm 150.31 & \pm 115.48 & \pm 141.02 \\
\hline Number/gram & $471.20^{\mathrm{a}}$ & $499.80^{\mathrm{ab}}$ & $463.60^{\mathrm{a}}$ & $718.80^{\mathrm{b}}$ \\
$(\mathrm{x} \mathrm{106})$ & \pm 239.73 & \pm 156.21 & \pm 106.37 & \pm 140.96 \\
\hline Mobility & $77.93^{\mathrm{a}}$ & $81.13^{\mathrm{a}}$ & $85.42^{\mathrm{a}}$ & $88.54^{\mathrm{a}}$ \\
$(\%)$ & \pm 18.36 & \pm 12.38 & \pm 6.35 & \pm 2.86 \\
\hline
\end{tabular}

Means with different superscript in the same row differed significantly ( $p>0.05) ; n$, number of animals 
Table 4. Effects of cottonseed cake on the percentage of males that ejaculated and some characteristics of the ejaculate

\begin{tabular}{lcccc}
\hline \multirow{2}{*}{ Parameters } & \multicolumn{4}{c}{ Level of incorporation of cottonseed cake $(\%)$} \\
\cline { 2 - 5 } & $0(\mathrm{n}=5)$ & $6(\mathrm{n}=5)$ & $12(\mathrm{n}=5)$ & $18(\mathrm{n}=5)$ \\
\hline Ejaculation rate & $100^{\mathrm{a}}$ & $100^{\mathrm{a}}$ & $100^{\mathrm{a}}$ & $100^{\mathrm{a}}$ \\
$(\%)$ & & & & \\
\hline Ejaculate volume & $1.36^{\mathrm{ab}}$ & $0.86^{\mathrm{a}}$ & $1.66^{\mathrm{b}}$ & $1.32^{\mathrm{ab}}$ \\
$(\mathrm{ml})$ & \pm 0.43 & \pm 0.09 & \pm 0.86 & \pm 0.55 \\
\hline Mobility & $86.36^{\mathrm{a}}$ & $79.97^{\mathrm{a}}$ & $88.99^{\mathrm{a}}$ & $69.67^{\mathrm{a}}$ \\
$(\%)$ & \pm 8.40 & \pm 9.66 & \pm 5.35 & \pm 24.72 \\
\hline Number/ml & $323.00^{\mathrm{a}}$ & $213.60^{\mathrm{a}}$ & $232.60^{\mathrm{a}}$ & $405.40^{\mathrm{a}}$ \\
$\left(\mathrm{x} 10^{6}\right)$ & \pm 33.46 & \pm 7.66 & \pm 10.36 & \pm 20.59 \\
\hline
\end{tabular}

Means with different superscript in the same row differed significantly different ( $p>0.05) ; n$, number of animals

The motility rate of ejaculated spermatozoa and the concentration of sperms in ejaculate were not significantly $(p>0.05)$ different among rabbit fed cottonseed cake and control.

The fertility rate (50\% control; $100 \%$ for treated bucks) and kids' mortality (0\% for control; $5 \%$ for treated rabbits) were comparable $(p>0.05)$. In contrast, no kidding was recorded with $18 \%$ cottonseed cake.

\section{Discussion}

The concentrations of cottonseed cake used in the present study did not affect the weight, the volume and the histological structure of genital organs. Those observations were not foreseeable because gossypol present in cottonseed cake is known to alter the development of reproductive organs in domestic animals (Hardley et al. 1981; Dongmo et al. 1993; El-Mahdy et al. 2005). Thus, El-Madhy et al. (2005) obtained œdematous testicles in rabbit receiving oral doses of gossypol as small as $4 \mathrm{mg} / \mathrm{kg}$ body weight per day. The higher concentration of cottonseed cake in this study did not produce such abnormalities. The trend to the increase in weight of testicle in the present study is not an indicator of œdema because no excessive interstitial space was seen on testes sections. The elevated weight would be associated with elements of the ration such as crude proteins and energy level that were higher in rations containing cottonseed cake (Rehm et al. 2008).
The normal structure of the testes (figure) shown by the histological section pointed out that cottonseed cake did not alter the testis. The absence of vacuole and the presence of all cell types on the seminiferous epithelium and on the lumen of the seminiferous tubule show that spermatogenesis had not been impeded.

The absence of significant difference in epididymal sperm characteristics between control rabbit bucks and those receiving cottonseed cake disagreed with the findings by Mohan (1989), Randel et al. (1992), Amini and Kamkar (2005), El-Mahdy et al. (2005), Taha et al. (2009) and Cunha et al. (2012). These findings would be due to the lack of influence of cottonseed cake (with characteristics reported in Table 1) at studied concentrations. In fact, the concentrations of gossypol delivered daily by cottonseed cake were lower than those generally causing adverse effects in domestic animals. The cauda epididymal sperm characteristics would be the expression of development and functioning of the testicle (Singer, 2005). Thus, the low sperm count is generally attributed to the germinal epithelium damage (Amini and Kamkar 2005), what was not observed on testis histological structure in cottonseed fed rabbits. Similarly, the comparability of volume of ejaculated sperm would be explained by the fact that the sperm is essentially secreted by accessory glands, in turn under the hormonal control of the testicle.

The decrease of spermatozoa mobility at $18 \%$ inclusion of cotton would be due to the high concentration of gossypol in that diet. Similar results have been obtained in rams at the dose of gossypol of $8.2 \mathrm{~g} /$ day. The sperm motility would be among the most gossypol sensitive reproductive parameters because no other studied parameter was affected by the treatment.

The fact that all rabbit bucks in the presence of female reacted, mounted, ejaculated or inseminated a female is a proof that leydig cells that are responsible of those behaviors were not altered in treated animals. The histological section validated this interpretation.

The fail of the reproductive performances in rabbit buck consuming a diet containing the 


\section{Cottonseed cake in rabbit buck reproduction}

highest concentration of cottonseed cake would be a consequence of the low motility of the buck germinal cell because the spermatozoon needs movement to go from the site of insemination to that of fertilization. In those bucks, sufficient number of spermatozoa was generated to initiate pregnancy. The absence of pregnancy in this batch might mean that the functionality of those spermatozoa was compromised.

\section{Conclusion}

The results seem to be more related to other elements of the diet than the gossypol. The adverse effects of this ingredient occurred at $18 \%$ inclusion. However the rate of inclusion of cottonseed cake is variable with its gossypol content. Consequently, it is not possible to generalize the upper limit of inclusion of cottonseed cake in the ration formulation.

\section{References}

Amini A, Kamkar F (2005). The effects of gossypol on spermatogenesis in NMRI mice. Iranian Journal of Science and Technology, 29: 12-28.

Amoa OA, Togun VA, Adjenumo DO (2012). Gonadal and extra-gonadal sperm characteristics of rabbit bucks fed cottonseed cake-based diets supplemented with vitamin E. Journal of Animal Science Advances, 2: 793-802.

Dabrowski k, Rinchard J, Lee KJ, Blom JH, Ciereszko A, Ottobre J (2000). Effects of diets containing gossypol on reproductive capacity of rainbow trout (Oncorhynchus mykiss). Biology and Reproduction, 62: 227-234.

Dongmo T, Pouilles D, Picard M, Mbi C, De Reviers M (1993). Use of cottonseed cake in poultry feed. Méd. Vét., 46: 5265.

El-Mahdy AR, EL-Nouty FD, Taha TA, Salem MH (2005). Reproductive toxicological effect of gossypol on male rabbits: semen characteristics and hormonal levels. Animal Science, 82: 259-269.

Hardley MA, Young C, Lin, Dim M (1981). Effects of gossypol on the reproductive system of male rats. Journal of Andrology, 2: 190199.
Jalees MM, Khan MZ, Saleemi MK, Khan A (2011). Effects of cottonseed meal on haematological, biochemical, and behavioural alterations in male japanese quail (Coturnix japonica). Pakistan Veterinary J ournal, 31: 211-214.

Mena $H$, Santos JEP, Huber JT, Terazon M, Calhoun MC (2004). The effects of varying gossypol intake from whole cottonseed and cottonseed meal on lactation and blood parameters in lactating dairy cows. Journal of Dairy Science, 87: 2506-2518.

Mohan J, Panda JN, Singh US, Moudgal PR (1989). Studies of antifertility effects of gossypol acetic acid in domestic cocks. J. Reprod. Fertil., 85: 73-78.

Randel RD, Chase CC, Wyse SJ (1992). Effects of gossypol and cottonseed products on reproduction of mammals. Journal of Animal Science, 70: 1628-1638.

Rehm S, White TE, Zahalka Ea, Stanislaus DJ, Boyce RW, Wier PJ (2008). Effects of Food Restriction on Testis and Accessory Sex Glands in Maturing Rats. Toxicologic Pathology, 36: 687-694.

Romualdo GS, Klinefelter GR, Kempinas WDG (2013). Post-weaning exposure to gossypol results in epididymis-specific effects throughout puberty and adulthood in rats. Journal of Andrology, 23: 220-228.

Singer PL, 2005. Pathways to pregnancy and parturition. Second revised edition. Cadmus professional communication. P. 44-79.

Taha A, Ali B, Mohamed H, Mostafa A, Massanyi P, Chlebec I (2009). In vitro gossypol induced spermatozoa motility alteration in rabbits. Domestic Animal Endocrinology, 37: 30-36.

Waites GM, Wang C, Griffin PD (1998). Gossypol: reasons for its failure to be accepted as a safe, reversible antifertility drug. Journal of Andrology, 21: 8-12.

WHO (2010). WHO laboratory manual for the examination and processing of human semen, $5^{\text {th }}$ Edition, P. 286. 